\title{
ПОЛИТИКАТА НА ОСМАНСКАТА ВЛАСТ СПРЯМО ПРЕСЕЛВАНЕТО НА БЪЛГАРИ В РУСКАТА ИМПЕРИЯ В НАЧАЛОТО НА 60-ТЕ ГОДИНИ НА ХІХ ВЕК
}

\section{В. Мучинов}

Мучинов В. Политиката на османската власт спрямо преселването на българи в Руската империя в началото на 60-те години на XIX век. В статията се проучва политиката на османската власт спрямо последната масова българска емиграция преди Освобождението на България - преселването на българи от Видинско и някои други райони от българските земи към южните владения на Руската империя през 1861-1862 г. Констатира се, че въпреки някои първоначални колебания, Високата порта предприема действия за максимално ограничаване на българската емиграция, а впоследствие полага усилия за завръщане на оцелелите български преселници обратно по родните им места. Анализират се причините за тази политика на османската власт, както и нейните последствия за българското национално развитие.

Ключови думи: миграционна политика; Руска империя; Османска империя; Видински санджак; Крим; българска емиграция; реемиграция.

Мучинов В. Политика османской власти в отношении переселения болгар в Российскую империю в начале 60-х годов XIX века. В статье рассматривается политика османской власти по отношению к последней массовой болгарской эмиграции до Освобождения Болгарии - переселению болгар из Видинского края и некоторых других районов болгарских земель в южные владения Российской империи в 1861-1862 гг. Констатируется, что, несмотря на некоторые первоначальные колебания, Высокая порта предприняла действия по максимальному ограничению болгарской эмиграции, а впоследствии положила усилия по возвращению уцелевших болгарских переселенцев обратно в их родные места. Анализируются причины этой политики османской власти, а также ее последствия для болгарского национального развития.

Ключевые слова: миграционная политика; Российская империя; Османская империя; Видинский санджак; Крым; болгарская эмиграция; реэмиграция.

Muchinov $\boldsymbol{V}$. The policy of the Ottoman rule regarding the Bulgarian emigration to the Russian Empire during the early 60s of the 19th century. This article examines the policy of the Ottoman rule in connection with the last mass Bulgarian emigration before the Liberation of Bulgaria - the resettlement of Bulgarians from the region of Vidin and some other areas of the Bulgarian lands to the southern areas of the Russian Empire in 1861-1862. It is noted that despite some initial hesitations the Sublime Porte took actions to minimize the Bulgarian emigration and subsequently endeavored to return the surviving Bulgarian migrants back to their homes. The reasons for this policy of the Ottoman rule are analyzed, as well as its consequences for the Bulgarian national development.

Keywords: migration policy; Russian Empire; Ottoman Empire; Vidin Sandzhak; Crimea; Bulgarian emigration; remigration.

Последната масова българска емиграция преди Освобождението на България се извършва в началото на 60-те години на XIX в., когато от намиращите се под османска власт български земи (най-вече от Северозападна България) към южните европейски владения на Руската империя се преселват над 12000 души. На тази емиграция обръщат внимание редица български изследователи - като се започне от проучванията на Г. Димитров и Д. Маринов от края на XIX и началото на XX в. и се стигне до публикациите на Е. Хаджиниколова, Ил. Тодев и Ст. Дойнов в последните няколко десетилетия ${ }^{1}$. Темата е засегната и от някои представители на чуждата историография като К. Карпат, Ив. Грек и Н. Червенков, Е. Белова, М. Фролова и др. ${ }^{2}$

Въпреки това все още редица аспекти, особено що се отнася до отношението и конкретните действия на Високата порта спрямо това преселение, остават слабо проучени и неуточнени. Именно „разплитането“ на политиката на централната и местната османска власт във връзка с преселническата акция от началото на 60-те години на XIX в. е основната цел на настоящата статия. За нейното реализиране, освен наличните български и чуждестранни проучвания, засягащи в една или друга степен разглеждания проблем, са използвани документи от български, турски, руски, западноевропейски и пр. произход, материали от тогавашния периодичен печат, спомени на дейци от епохата и др. ${ }^{3}$

(C) Мучинов, В., 2015 
За разлика от предишните големи емиграционни движения, които се извършват по време и непосредствено след руско-турските войни от 1806-1812, 1828-1829 и 18531856 г., емиграцията от началото на 60-те години на XIX в. се извършва в мирновременна обстановка. Тя е пряко свързана с големите размествания на населението в Северното Причерноморие, Крим и Кавказ в годините, последвали края на Кримската война. Масовите размери, които взема преселването на кримските татари и ногаите от Южна Русия към владенията на Османската империя ${ }^{4}$, принуждават руското правителство да разреши официално този процес в края на 1859 г. Заедно с това управляващите в Петербург вземат решение да се поощри заселването в Русия на известен брой балкански славяни, най-вече българи, които да заместят в демографско и стопанско отношение изселилите се татари. Инструкции в този дух са изпратени в началото на 1860 г. до руските консули на Балканите, включително до тези във Видин, Варна и Одрин

По този начин от руска страна е стартирана подготовката за извършването на поредната преселническа акция от българските земи, осъществена през 1861-1862 г. Най-голям мащаб тази акция приема в Северозападна България (Видинско, Белоградчишко и Ломско), поради което фигурира в българската историография и под името „Видинско преселване“. Причините за успеха на руската агитация в този регион се тьрсят в нерешения с десетилетия аграрен въпрос, който тласка неколкократно през 30-50-те години на XIX в. местното българско население към бунтове и изселвания в съседна Сърбия ${ }^{6}$ Към този проблем се прибавя и преселването на татарите в района през 1860-1861 г., което допълнително утежнява положението на християнското население в северозападните български земи ${ }^{7}$. Поради това местните български селяни масово се поддават на уверенията на руския консул във Видин М. А. Байков, че в Русия те ще намерят всичко необходимо за добър и спокоен живот и най-вече - достатъчно количество обработваема земя и привилегии. Руските агенти изтъкват и други аргументи в полза на преселването - сьгласието на турските власти за неговото извършване и възможността за предварителна продажба на недвижимото имущество, осигуряване на безплатно пътуване до местата на заселване в Южна Русия и пр. ${ }^{8}$

В резултат на тази активна агитация през периода от края на юли до началото на октомври 1861 г. от Видинския санджак се изселват 1560 семейства или общо 10990 българи. Те са превозени с кораби и шлепове до делтата на р. Дунав и оттам през Черно море до южноруските пристанища Одеса, Евпатория и Теодосия (последните две - разположени на Кримския полуостров) ${ }^{9}$. Далеч по-скромни резултати обаче са постигнати в останалите части от българските земи. Въпреки предварителните очаквания на руските дипломатически представители във Варна, Одрин и Битоля и проведената активна агитация, емиграцията от Североизточна България, Тракия и Македония обхваща ограничен кръг хора ${ }^{10}$. Едва през май 1862 г. в Крим пристигат 229 семейства от Одринско и отделни български семейства от Североизточна България (от Шуменско, Русенско и Тулчанско). Заедно с тях общият брой на преселниците от 1861-1862 г. надхвърля 12000 души ${ }^{11}$.

Основен проблем за настоящото изследване е изясняването на политиката на османската власт спрямо тази преселническа акциия. Дълги години остава спорен въпросът дали съществува договореност между правителствата в Петербург и Цариград относно размяната на население между двете империи. Различните мнения по този въпрос са обобщени от Ст. Дойнов, който, опирайки се на руски дипломатически документи, твърди, че през февруари 1861 г. е постигнато подобно споразумение на ниво посланици. Действително, в донесение до канцлера А. М. Горчаков от 22 февруари 1861 г. руският посланик в Цариград А. Б. Лобанов-Ростовски докладва, че същия ден е официално уведомен от османския министър на външните работи Али паша за съгласието на Високата порта да предостави на желаещите да се преселят в Русия българи това право ${ }^{12}$.

Очевидно е, че това съгласие на османското правителство е обвързано с въпроса за преселването на мюсюлманите от Южна Русия в Османската империя. Трябва да се отчете, че след Кримската война сред част от османския управляващ елит се разпространява идеята за извършване на размяна на християнските поданици на султана с мюсюлмански имигранти (предимно татари и черкези) от руските владения в Крим и Кавказ. Привържениците на подобна размяна считат, че нейното реализиране ще донесе безспорни политико-стратегически предимства за Османската империя - проявяващите симпатии към Русия християнски поданици на султана ще бъдат заменени от изпитващите силна враждебност 
към руската политика татари и черкези ${ }^{13}$. Преобладаващата част от османските държавници обаче ясно съзнават, че такава размяна би донесла тежки икономически проблеми за Империята и би влошила и без това незавидното ѝ финансово състояние ${ }^{14}$. Именно поради това те се противопоставят на провеждането на подобна политика и на изпълнението от страна на Високата порта на споразумението от февруари 1861 г.

Последвалите действия на османската власт показват, че поне на първо време Високата порта е склонна да допусне ограничен емиграционен поток от своите владения в Румелия и по-конкретно от северозападните български земи. Не е случайно, че тъкмо в Северозападна България османската власт проявява най-голяма пасивност спрямо руската агитация и на практика позволява преселническите настроения сред местното българско население да вземат големи размери. Причината за това може да се търси в напрегнатата обществено-политическа обстановка в северозападните български земи. Посредством допускането на ограничена българска емиграция от Видинския санджак османската власт по всяка вероятност се стреми да тушира бунтовническите настроения сред местното българско население, като позволи на най-радикалните негови елементи да се изселят в Русия заедно със своите семейства. Тази хипотеза се подкрепя от факта, че най-голям размер българската емиграция взема сред жителите на тези села във Видинско, Белоградчишко и Ломско, които вземат най-дейно участие във въстанието от 1850 г. $^{15}$

Твърде скоро обаче на османското правителство се налага да заеме категорична позиция срещу българското изселване. Руската дипломация използва устното споразумение от началото на 1861 г. като основание за предприемане на широкомащабна преселническа кампания: през следващите месеци руските консулски мисии (особено тези във Видин, Варна и Одрин) разгръщат трескава агитационна дейност сред християнското население в Румелия ${ }^{16}$. Това принуждава османските управляващи да предприемат мерки за предотвратяване на надигащата се значителна преселническа вълна.

Още на 30 април 1861 г. Високата порта изпраща писмо до провинциалните власти в северните български земи, в което се посочва, че „някои подстрекатели“, с цел да създадат бунт в страната, разпространяват слухове, че заселването на черкезите и ногаите ще се извърши в замяна на изселването на българите. На местните власти в Северна България се нарежда да вземат енергични мерки срещу разпространителите на подобни неверни и злонамерени слухове. За да се успокоят духовете сред българския народ, е необходимо местните български първенци да бъдат уверени, че държавата счита българите за „,дни от най-благонадеждните османски поданици“, за чието добруване се полагат под покровителството на султана най-големи грижи. Също така трябва да им бъде разяснено, че мюсюлманските бежанци са разпратени за заселване на подходящи свободни места не само в Северна България, но и в други части на Империята, при това в много по-голямо количество ${ }^{17}$.

Високата порта обръща специално внимание на ситуацията във Видинско, където, както вече се посочи, агитацията за преселване е най-дейна. През юни 1861 г. на видинския валия е наредено да вземе мерки за ограничаване на контактите между българите и руския консул във Видин ${ }^{18}$. Интензивната кореспонденция между видинския валия и централната власт в Цариград продължава и през следващите месеци. Портата нарежда да се попречи на тези, които имат намерение да се изселят, но без да се употребява насилие спрямо тях, тъй като това ще даде повод за оплаквания. Поради това властите във Видинско и съседните райони се призовават да постъпват в случая „твърде разумно“19.

На 18 ноември 1861 г. Портата изпраща тайна заповед до провинциалните власти в Румелия, в която се съобщават решенията на Министерския съвет в Цариград, нарочно свикан по въпроса за изселването на българите. А те са: 1. Дьржавата няма да задържа със сила онези, които не разбират грижите и свободите, с които са дарени от султана, и напускат огнищата си „под миража на смътни обещания“; 2. На българите, които желаят да се изселят, трябва да се съобщи, че Османската империя не е канила и не поощрява идването на мухаджири (мюсюлмански бежанци), а последните се преселват по собствено желание и с позволението на Русия. Заявява се, че османската власт „няма абсолютно никакъв договор с Русия за отправяне на българи от Румелия на местата, изпразнени от мухаджирите в Русия“". Поради това разпространяваните злоумишлени слухове за изселване на българите са неверни и българският народ не трябва да им се доверява.

Посочените решения трябва да се обяснят на духовните ръководители и на другите първенци измежду българите, с които местните власти се задължават да проведат специ- 
ални срещи. Нещо повече - заявява се, че ако някои българи в желанието си да напуснат страната са продали имотите си, то те ще се отнемат от купувачите и ще се врьщат обратно на собствениците. Подчертава се, че за да се постигне пълно успокояване на българското население, то не бива да се измъчва и преследва, а напротив - към него местните власти трябва да се отнасят „добре и справедливо“20.

Въпреки заявлението, че държавата няма да задържа със сила тези, които желаят да се изселят, в края на 1861 г. са предприети мерки срещу големите размери, които придобива агитацията за преселване в Търновско, Варненско, Одринско и други райони в българските земи, като някои от агитаторите са прогонени, а други - арестувани. С активни действия за спиране на преселническото движение се отличават варненският мютесариф Ашир бей и бившият велик везир Мехмед Къбръзль паша, назначен през есента на 1861 г. за одрински валия. Комбинираните мероприятия, съчетаващи мирното увещаване със силовите действия, продължават и през следващата 1862 г. ${ }^{21}$

Именно взетите мерки от страна на централната и местната османска власт, заедно с надигналото се възмущение сред българската общественост от „убийствената“ (по определението на Г. С. Раковски ${ }^{22}$ ) преселническа политика на руския царизъм, довеждат до значителното ограничаване на емиграцията от българските земи през 1861-1862 г. Така преселническата акция се осъществява единствено в част от Северозападна България, докато изселванията от другите райони на българското етническо пространство имат твърде незначителен характер.

Изложената информация дава възможност да се заяви, че въпреки наличието сред османските управляващи среди в годините след Кримската война на идеи за извършване на размяна на християнските поданици на султана с мюсюлмански имигранти от руските владения в Крим и Кавказ, отново (както и в предишните десетилетия на XIX в ${ }^{23}$ ) в политиката на Високата порта взема връх линията за максимално ограничаване на емиграцията на християнското население от българските земи.

Както вече се посочи, запазването на тази линия в политиката на Високата порта е продиктувано най-вече от икономически и фискални съображения. Очакванията на някои крьгове сред османските управляващи, че пристигащите от Русия мюсюлмански колонисти ще заместят емигриралите през 1861 г. от Видинско българи в стопанско отношение, твърде скоро показват своята несъстоятелност. Българската емиграция довежда до замиране на земеделието в редица райони на Северозападна България ${ }^{24}$, което принуждава Високата порта не само да вземе мерки за ограничаване на по-нататъшната емиграция на своите християнски поданици, но и да предприеме активни действия за връщане в пределите на Османската империя на вече изселилите се българи.

Реализацията на тази цел от страна на османското правителство се благоприятства от лошата руска организация по транспортирането и настаняването в Крим на българските преселници от Видинско, което поражда сред тях масово желание за заврьщане в намиращите се под османска власт български земи. Още през есента на 1861 г. някои представители на българските емигранти влизат в контакт с османското консулство в Одеса, а в началото на 1862 г. преселниците от над 30 видински, белоградчишки и ломски села избират делегация, която да измоли от султана помощ за връщане по родните им места. В съставеното по случая писмо селяните от Видинско молят и за предоставяне на временни данъчни облекчения, за да могат да възстановят своите стопанства след заврьщането си ${ }^{25}$.

Опитите на руските власти да разубедят българските преселници от решението им за заврьщане в родината са неуспешни, като с малки изключения българите остават непреклонни в своите намерения. В крайна сметка през март 1862 г. османският консул в Одеса е официално информиран за съгласието на руското правителство за връщане на преселниците. Според постигнатите през април договорености руската страна поема ангажимента да доведе до пристанищата желаещите да се завърнат в Османската империя и да ги снабди с храна за няколко денонощия. Всички останали разходи трябва да се поемат от Високата порта. През май 1862 г. изпратените от османското правителство кораби транспортират от пристанищата в Крим до Видин около 8000 български бежанци. В Русия остават само 160 семейства (около 800 души), най-вече на лица, компрометирали се пред своите сънародници заради усърдието си по извършването на преселването. За по-малко от една година около 2000 бежанци умират от болести, недохранване и измръзване по време на тежкото пътуване към Южна Русия и прекараната там сурова зима ${ }^{26}$. 
Високата порта дава нареждания на местните власти в българските земи за полагането на специални грижи по посрещането, настаняването и подпомагането на изстрадалите преселници. По-голямата част от тях се завръщат в родните си села във Видинско, но има и някои, които по време на реемиграцията се установяват в Северна Добруджа. Удовлетворена е молбата на завърналите се български преселници от Видинско за опрощаване на данъците им за период от няколко години; полагат се усилия за регулиране на проблемите, възникнали поради настаняването на част от татарските и черкезките колонисти в селата и домовете на завърналите се български изселници, като за целта правителството решава да им се раздадат земи от държавния поземлен фонд ${ }^{27}$. Както основателно посочват изследователи като С. Дамянов и Ст. Дойнов, всичко това е сторено с цел да се възстанови по-бързо замрялото след българското изселване селско стопанство в Северозападна България ${ }^{28}$. Не трябва обаче да се пропускат и политическите съображения за благосклонното отношение на Високата порта спрямо българските реемигранти - османските управляващи разчитат, че положените усилия за завръщането и подпомагането на преселниците ще засилят лоялността на българското население в този стратегически регион към властта на султана и ще предотвратят бъдещото му въвличане в бунтовни кроежи от страна на руски или сръбски агенти ${ }^{29}$.

Настаняването на българските реемигранти обратно в родните им населени места обаче не минава без проблеми. По време на пътуванията си из Дунавска България през 60-70-те години на XIX в. Ф. Каниц констатира, че години след завръщането им положението на някои от реемигрантите все още не е уредено. Така например през 1864 г. завърналите се в с. Василовци, Ломско, български селяни все още са принудени да живеят в примитивни землянки, тъй като напуснатите им през 1861 г. домове са заети от татарски колонисти. Същото е положението и на завърналите се български жители на с. Вълчитрън, Плевенско ${ }^{30}$.

Посочените проблеми обаче не са в състояние да променят констатацията, че реемиграцията на българските преселници от Южна Русия през 1862 г. представлява безспорен успех за османската политика. Завръщането на емигрантите се използва от османската власт за изобличаване на руската политика, довела до разорението и страданията на подлъганите да се преселят в „кримските пустини“ българи от Видинско, както и за пропагандиране на „благоденствието“ и „спокойствието“, в което живеят българският и другите народи под грижите на османското правителство ${ }^{31}$.

В заключение може да се заяви, че предприетата (въпреки някои първоначални колебания) политика от страна на османската власт спрямо българската емиграция към Руската империя в началото на 60-те години на XIX в. довежда не само до значително ограничаване на нейните мащаби, но и до полагането на целенасочени усилия за завръщането на оцелелите български преселници обратно по родните им места. За българското национално развитие осъществяването на тази политика на Високата порта има голямо значение, тъй като допринася за съхраняването на българския демографски потенциал на прага на Освобождението и стимулира по-нататъшното обществено-икономическо развитие на българските земи.

${ }^{1}$ Маринов Д. Политически движения и въстания в Западна България (Видинско, Ломско, Белоградчишко и Берковско): Принос за българската история // Сборник за народни умотворения, наука и книжнина. - Кн. 2. - София, 1890. - С. 61-114; Маринов Д. Избрани произведения в 5 тома. - Т. 3 : История на града Лом и Ломска околия / Под ред. и с бележки на Д. Господинов. - София, 2003. С. 442-483; Димитров Г. Княжество България в историческо, географическо и етнографическо отношение. - Ч. 2. - Пловдив, 1896. - С. 196-197; Тодоров-Хиндалов В. Изселване на видинските българи в 1861 г. // Тодоров-Хиндалов В. Възстания и народни движения в предосвободителна България според новооткрити турски официални документи. - София, 1929. - С. 93-111; Дамянов С. Ломският край през Възраждането. Икономически живот и политически борби. - София, 1967. - С. 190-205; Митев Й. Георги Раковски и емигрирането на българи в Русия през 1861 г. // Военноисторически сборник. - 1970. - Кн. 3. - С. 3-23; Тонев В. Някои данни за преселническото брожение в Източна България през 1861 г. // Известия на Народния музей - Варна. - 1973. - Кн. 9. - С. 185-195; Трайков B. Георги Стойков Раковски. Биография. - София, 1974. - С. 196-209; Хаджиниколова Е. Някои въпроси по преселването на българи в Русия през 1861 г. // Исторически преглед. - 1976. - Кн. 6. - С. 45-61; Хаджиниколова Е. Българските преселници в южните области на Русия 1856-1877. - София, 1987. - С. 31-44; Тодев Ил. О балканской политике России в начале 60-х годов ХІХ столетия // 
Bulgarian Historical Review. - 1988. - Кн. 3. - С. 42-57; Плетньов Г. Руските консули и преселването на българи в Русия през 1860-1862 година // Военноисторически сборник. - 1992. - Кн. 4. - С. 63-84; Дойнов Сm. Последното масово преселение в Южна Русия (1861-1862) // Исторически преглед. 1992. - Кн. 11-12. - С. 18-39; Дойнов Cm. Георги С. Раковски и последното голямо преселване в Русия // Българско възраждане: идеи, личности, събития. Годишник на Общобългарския комитет „Васил Левски“. - Т. 4. - София, 2002. - С. 324-334; Дойнов Сm. Едно неуспешно преселване на българи в Южна Русия // Studia Balcanica 24: Изследвания в чест на проф. Веселин Трайков. - София, 2003. - С. 328-337; Тодев Ил. Демографски процеси // История на българите. - Т. 2: Късно средновековие и Възраждане. - София, 2004. - С. 389-402; Дойнов Ст. Българите в Украйна и Молдова през Възраждането (1751-1878). - София, 2005. - С. 137-159; Пеев В. Преселението на българите в Русия от 1861 г. и Добродетелната дружина // Университетски четения и изследвания по българска история. IV международен семинар Смолян, 11-13 май 2006 г. / Състав. И. Баева, Пл. Митев. - София, 2008. - C. 214-226.

${ }^{2}$ Karpat K. Ottoman Population 1830-1914. Demographic and Social Characteristics. - Madison, Wis.: The University of Wisconsin Press, 1985. - Р. 63-65; Грек Ив. Българите от Украйна и Молдова. Минало и настояще / Ив. Грек, Н. Червенков. - София, 1993. - С. 35-36; Белова Е.В. Миграционная политика на Юге Российской империи и переселение болгар в Новороссийский край и Бессарабию (1751-1871 гг.). - Москва, 2004. - С. 175-221; Фролова М.М. Русское консульство в Видине и переселение болгар в Россию (1861 г.) // Славянский мир в третьем тысячелетии. Славянские народы: векторы взаимодействия в Центральной, Восточной и Юго-Восточной Европе. - Москва, 2010. С. 170-187; Пачев С. Причины массового переселения болгар в Таврическую губернию 1861-1863 гг. в историографии // Известия на Института за исторически изследвания. - Т. 31 : Сборник в чест на проф. д.и.н. Стефан Дойнов. - София, 2014. - С. 317-326; Фролова М. Переселенческие настроения у болгар Битольского эялета в 1861 г. (По донесениям русского дипломата М.А. Хитрово) // Известия на Института за исторически изследвания. - Т. 31: Сборник в чест на проф. д.и.н. Стефан Дойнов. София, 2014. - С. 416-428, и др.

${ }^{3}$ Раковски Г. С. Преселение в Русия или руската убийствена политика за българите. - Букурещ, 1861. 2. изд. София, 1886; Из архивата на Найден Геров / Под ред. на Т. Панчев. - Кн. 1-2. - София, 1911-1914; Тодоров-Хиндалов В. Изселване на видинските българи... - С. 100-111; Селищев А. О переселении македонских болгар в Россию и греко-болгарских спор в Битольской и Охридской областях (Из консульских донесений 1861-1874 гг.) // Македонски преглед. - 1929. - Кн. 4. - С. 27-45; Документи за българската история (по-нататък - ДБИ). - Т. 1: Архив на Найден Геров. - Ч. 1 (18571870 ) / Под ред. на М.Г. Попруженко. - София, 1931; ДБИ. - Т. 3: Документи из турските държавни архиви (1564-1908). - Ч. 1: (1564-1872) / Подбрал и превел П. Дорев. - София, 1940; Архив на Г. С. Раковски. - Т. 1-4. - София, 1952-1969; Документи за българската история из германските архиви 1829-1877 / Състав. и ред. Хр. Христов и В. Паскалева. - София, 1963; Русия и българското национално-освободително движение 1856-1876. Документи и материали. - Т. 1. - Ч. 1-2. - София, 1987; Граф Н. П. Игнатиев. Дипломатически записки (1864-1874). Донесения (1865-1876). - Т. 1: Записки (1864-1871). - София, 2008; Граф Н. П. Игнатиев. Дипломатически записки (1864-1874). Донесения (1865-1876). - Т. 2: Записки (1871-1874) \& Донесения (1865-1876). - София, 2009; и др.

4 За татарската емиграция от Крим и Кубан в годините след Кримската война и за настаняването на значителна част от татарските преселници в намиращите се под османска власт български земи вж. по-подробно: Михайлова-Мръвкарова М. Етнокултурни процеси у кримските татари от Североизточна България // Съдбата на мюсюлманските общности на Балканите. - Т. 4: Ислям и култура. Изследвания. - София, 1999. - С. 446-449; Антонов С. Татарите в България. - Добрич, 2004. - С. 52-62; Мучинов B. Миграционна политика на Османската империя в българските земи през XIX век (до 1878 г.). - София, 2013. - C. 159-171; Karpat K. Ottoman Population... - P. 66.

5 Русия и българското национално-освободително движение... - Т. 1. - Ч. 1. - С. 497; Граф Н.П. Игнатиев. Дипломатически записки... - Т. 1. - С. 87-89; Хаджиниколова Е. Българските преселници... - С. 31-32; Плетньов Г. Руските консули... - С. 68-69; Дойнов Ст. Българите в Украйна и Молдова... - С. 124-131; Белова E.B. Миграционная политика на Юге Российской империи... C. $176-181$.

По-различно мнение за целите на руската политика излага Ил. Тодев. Според него с преселването на българите руските управляващи целят да ограничат разпространението на униатството в българските земи и да запазят единството на православието (вж. Тодев Ил. О балканской политике России... - С. 42-57; Тодев Ил. Демографски процеси... - С. 397-402).

${ }^{6}$ Маринов Д. Политически движения и въстания в Западна България... - С. 61-114; Димитров Cmp. Сърбия и въстанически движения в Западна България от 30-те-40-те години на XIX век // Studia Balcanica 2: Проучвания по случай Втория международен конгрес по балканистика. - София, 1970. - С. 247-280; Димитров Стр. Въстанието от 1850 година в България. - София, 1972; История на България. - Т. 5: Българско възраждане (XVIII - средата на XIX век). - София: Издателство на БАН, 1985. - С. 332-384; Плетньов Г. Руските консули... - С. 67-68; Генчев Н. Българското въ3раждане. - 4. доп. изд. - София, 1995. - С. 216-229; Митев П. Българското възраждане. Лекционен 
курс. - София, 1999. - С. 45-52; Маждракова-Чавдарова О. За приноса на Северозападна България в националноосвободителното движение след въстанието от 1850 г. // Националноосвободителните движения в българските земи XV-XIX век и тяхното отразяване в музеите. Сборник с доклади и научни съобщения от Юбилейна национална научна конференция в Чипровци, 2008. - София, 2012. - С. 17-24; Мучинов B. Миграционна политика на Османската империя... - С. 79-83.

${ }^{7}$ На някои места във Видинско дори се стига до открити сблъсъци между татарските преселници и местните български селяни, които са недоволни от наложените им допълнителни задължения във връзка с превозването и настаняването на мюсюлманските бежанци, на които трябва да строят къщи и да предоставят земи, селскостопански инвентар и храни (вж. Документи за българската история из германските архиви... - С. 371; Маринов Д. Политически движения и въстания в Западна България... - С. 109-110; Маринов Д. Избрани произведения... - Т. 3. - С. 445; Димитров Г. Княжество България... - Ч. 2. - С. 196-197; Попов Д. Град Лом и околията му... - С. 117; Тодоров-Хиндалов $B$. Изселване на видинските българи... - С. 95; Дамянов С. Ломският край през Възраждането... - С. 64-66, 190-192; Заяков Н. Татарски и черкезки поселения във Видинско през третата четвърт на XIX век // Известия на музеите в Северозападна България. - 1986. - Т. 11. - С. 117; Хаджиниколова Е. Българските преселници... - С. 31-32; Антонов С. Татарите в България... - С. 58).

${ }^{8}$ Маринов Д. Избрани произведения... - Т. 3. - С. 445-446; Тодоров-Хиндалов В. Изселване на видинските българи... - С. 96; Дамянов С. Ломският край през Възраждането... - С. 192-193; Плетньов Г. Руските консули... - С. 72-73; Дойнов Ст. Българите в Украйна и Молдова... - С. 137-144; Белова Е.В. Миграционная политика на Юге Российской империи... - С. 187-188; В съвременната руска историография се правят настоятелни опити да се отрече активната роля на руските консули и агенти за засилване на преселническите настроения сред българското население във Видинско и други райони от османските владения на Балканите (вж. напр. Фролова М.M. Русское консульство в Видине... - С. 170-187).

${ }_{9}^{9}$ Русия и българското национално-освободително движение... - Т. 1. - Ч. 2. - С. 168-172; Плетньов Г. Руските консули... - С. 78-79; Дойнов Сm. Българите в Украйна и Молдова... - С. 137-144; Белова Е.В. Миграционная политика на Юге Российской империи... - С. 201-209; Фролова М.М. Русское консульство в Видине... - С. 179-180. Трябва да се отбележи, че в някои изследвания се посочват и по-високи стойности за преселниците от Видинско. Според Д. Маринов в Русия се преселват около 16400 души от Северозападна България (вж. Маринов Д. Политически движения и въстания... - С. 110-112; Маринов Д. Избрани произведения... - Т. 3. - С. 482). Тази стойност се подкрепя и от други автори, като С. Дамянов и Е. Хаджиниколова (вж. Дамянов С. Ломският край през Възраждането... - С. 192-193, 203; Хаджиниколова Е. Българските преселници... - С. 42-43).

${ }^{10}$ Особена активност за осъществяване на руската преселническа политика освен видинския консул М. А. Байков проявяват и руските консули във Варна и Одрин - съответно А. В. Рачински и Н. П. Шишкин. За разлика от тях, пловдивският вицеконсул - българинът Найден Геров, има подчертано резервирано отношение към тази преселническа акция, която счита за предварително осъдена на неуспех. Съображения срещу преселването на българи от Македония изказва и битолският вицеконсул М. А. Хитрово (вж. по-подробно по въпроса: Български книжици. - 1861. - Г. IV. - Бр. 23. - С. 445-447; Из архивата на Найден Геров... - Кн. 2. - С. 664-665; ДБИ. - Т. 1: Архив на Найден Геров... - Ч. 1. - С. 207, 230-232, 260-266; Селищев А. О переселении македонских болгар в Россию... - С. 27-36; Тонев В. Някои данни за преселническото брожение... - С. 185-195; Плетньов Г. Руските консули... - С. 72-78; Дойнов Ст. Българите в Украйна и Молдова... - С. 145-148).

${ }_{11}$ Плетньов Г. Руските консули... - С. 79; Дойнов Сm. Българите в Украйна и Молдова... C. 148; Karpat K. Ottoman Population... - P. 64.

12 Русия и българското националноосвободително движение... - Т. 1. - Ч. 2. - С. 12-13, 53-54; Хаджиниколова Е. Българските преселници... - С. 35-36; Плетньов Г. Руските консули... - С. 69; Дойнов Ст. Българите в Украйна и Молдова... - С. 127-129; Белова Е.В. Миграционная политика на Юге Российской империи... - С. 189-191.

${ }^{13}$ Сред привържениците на подобна размяна са и някои високопоставени служители в османската провинциална администрация. Сред тях по всяка вероятност се нарежда софийският мютесариф Хасан Тахсин паша, който през лятото на 1861 г. заплашва софийските българи, които не признават властта на назначения от Вселенската патриаршия митрополит Доротей, с изселване в Крим на мястото на преселващите се в Османската империя татари (вж. Дунавски лебед. - 1861. - Г. І. - Бр. 41. - 11 юли; Дунавски лебед. - 1862. - Бр. 42. - 18 юли).

14 Дамянов С. Ломският край през Възраждането... - С. 191-192; Тонев В. Някои данни за преселническото брожение... - С. 186; Плетньов Г. Руските консули... - С. 70; Тодев Ил. Д-р Стоян Чомаков (1819-1893). Живот, дело, потомци. - Ч. 1: Изследване. - София, 2003. - С. 204-205.

${ }^{15}$ Маринов Д. Избрани произведения... - Т. 3. - С. 446; Дамянов С. Ломският край през Възраждането... - С. 192-193.

${ }^{16}$ Плетньов Г. Руските консули... - С. 72-78; Дойнов Ст. Българите в Украйна и Молдова... С. $137-148$.

${ }^{17}$ ДБИ. - Т. 3: Документи из турските държавни архиви... - Ч. 1. - С. 404-405. 
${ }^{18}$ Пак там. - C. 409.

${ }^{19}$ Пак там. - С. 416-417.

${ }^{20}$ Пак там. - С. 421.

${ }^{21}$ Български книжици. - 1861. - Г. IV. - Бр. 23. - Декември. - С. 448-449; ДБИ. - Т. 3: Документи из турските държавни архиви... - Ч. 1. - С. 424-425; Архив на Г. С. Раковски... - Т. 3. - С. 825, 832; Русия и българското националноосвободително движение... - Т. 1. - Ч. 2. - С. 162-165, 229-230; Тонев В. Някои данни за преселническото брожение... - С. 189-194; Тодев Ил. О балканской политике России... - С. 49-50; Тодев Ил. Демографски процеси... - С. 399-400; Дойнов Ст. Българите в Украйна и Молдова... - С. 145-146; Белова E.B. Миграционная политика на Юге Российской империи... - С. 211-213.

${ }^{22}$ Раковски Г. С. Преселение в Русия или руската убийствена политика за българите. - Букурещ, 1861. 2. изд. - София, 1886; Вж. също Митев Й. Георги Раковски... - С. 3-23; Трайков В. Георги Стойков Раковски. Биография... - С. 196-209; Дойнов Ст. Георги С. Раковски и последното голямо преселване в Русия... - С. 324-334.

${ }^{23}$ Относно политиката на османската власт за ограничаване на емиграционните движения от българските земи през първата половина на XIX век и по време на Кримската война от 1853-1856 г. вж. по-подробно Мучинов В. Миграционна политика на Османската империя... - С. 72-87.

${ }_{24}^{24}$ Дамянов С. Ломският край през Възраждането... - С. 66-67.

25 ДБИ. - Т. 3: Документи из турските държавни архиви... - Ч. 1. - С. 418-419; Маринов Д. Политически движения и въстания в Западна България... - С. 111-112; Маринов Д. Избрани произведения... - Т. 3. - С. 480-481; Дамянов С. Ломският край през Възраждането... - С. 200-201; Хаджиниколова Е. Българските преселници... - С. 43-44; Плетньов Г. Руските консули... - С. 80-82; Дойнов Сm. Българите в Украйна и Молдова... - С. 143-157; Белова E.В. Миграционная политика на Юге Российской империи... - С. 210-211; Karpat K. Ottoman Population... - P. 64-65.

${ }^{26}$ Хаджиниколова Е. Българските преселници... - С. 42-44; Грек Ив. Българите от Украйна и Молдова... / Ив. Грек, Н. Червенков. - С. 35; Дойнов Сm. Българите в Украйна и Молдова... - С. 157158; Karpat K. Ottoman Population... - P. 65.

${ }^{27}$ Цариградски вестник. - 1862. - Г. ХІІ. - Бр. 20. - 12 май; ДБИ. - Т. 3: Документи из турските държавни архиви... - Ч. 1. - С. 422-440; Маринов Д. Политически движения и въстания в Западна България... - С. 112; Маринов Д. Избрани произведения... - Т. 3. - С. 481-482; Димитров Г. Княжество България... - Ч. 2. - С. 197; Тодоров-Хиндалов В. Изселване на видинските българи... - С. 98-99; Дамянов С. Ломският край през Възраждането... - С. 201-204; Дойнов Сm. Българите в Украйна и Молдова... - С. 157-158; Karpat K. Ottoman Population... - P. 65.

${ }_{28}$ Дамянов С. Ломският край през Възраждането... - С. 66-67; Дойнов Cm. Българите в Украйна и Молдова... - С. 158-159.

29 ДБИ. - Т. 3: Документи из турските държавни архиви... - Ч. 1. - С. 439-440.

${ }^{30}$ Каниц $\Phi$. Дунавска България и Балканът. Историко-географско-етнографски пътеписни проучвания от 1860 до 1879 г. - Т. 1. - 2. прераб. изд. - София, 1995. - С. 124; Т. 2. - С. 40; Колкото и да е парадоксално, за разрешаването на своите проблеми някои от завърналите се български селяни се обръщат за съдействие към руските консулски служби на Балканите (вж. Белова Е.В. Миграционная политика на Юге Российской империи... - С. 216-217).

${ }^{31}$ Дунав. - 1867. - Г. III. - Бр. 165. - 9 апр.; Дунав. - 1868. - Г. IV. - Бр. 260. - 13 март. 